\title{
SECONDARY METABOLITE SCREENING IN CHARCOAL FROM WASTE OF KERANDANG FISH (CHANNA PLEUROPHTHALMA BLKR) ORIGINATED FROM CENTRAL KALIMANTANESE
}

\author{
Aryani* $^{*}$ \\ Department of Fisheries, Faculty of Agriculture, University of Palangka Raya \& Postgraduate \\ Program, Faculty of Fisheries and Marine Science, University of Brawijaya, Indonesia \\ Suprayitno Eddy, Sasmito Bambang Budi, Hardoko \\ Faculty of Fisheries and Marine Sciences, University of Brawijaya, Indonesia \\ *E-mail: aryani.binti69@gmail.com
}

\begin{abstract}
.
Kerandang fish (Channa pleurophthalmus Blkr) is one of the potential fish from the Channidae family in Central Kalimantan. The potential of Kerandang fish has so far not been much researched/ explored, causing a lack of scientific information about secondary metabolites found in charcoal from waste of Kerandang fish (Channa pleurophthalmus Blkr). The aim of this study is to find out and obtain an overview of the content of the secondary metabolites contained in charcoal from waste of Kerandang fish (Channa pleurophthalmus Blkr), namely scalp, scales, dorsal fin, pectoral fin, pelvic fin, anal fin and caudal fin, which could potentially be used in the field of health/ pharmaceutical as a cure for allergies (local wisdom). The results of this study are expected to provide useful information about groups of the secondary metabolites in charcoal from Kerandang fish (Channa pleurophthalmus Blkr) which has the potential to be anti-allergic. The study is carried out by screening and identifying the secondary metabolites using a color test, which includes the following parameters: flavonoids, alkaloids (meyer, dragendorf, bouchardat), tannins, terpenoids (steroids, triterpenoids), polyphenols and saponins. The data obtained are presented in a table form and analyzed descriptively. The extraction is carried out by maceration method using $70 \%$ ethanol solvent. The screening and identification show that the secondary metabolites contained in the ethanol extract of charcoal from waste of Kerandang fish (Channa pleurophthalmus Blkr) with color test are as follows: (-) flavonoids, (-) alkaloids, (-) tannins, (-) terpenoids, (-) polyphenols, and (+) saponins. Saponins are found in ethanol extract of charcoal from waste of Kerandang fish (Channa pleurophthalmus Blkr), which are characterized by the formation of permanent foam.
\end{abstract}

\section{KEY WORDS}

Secondary metabolites, charcoal, waste, Kerandang fish.

Fish is one of the food substances which contain various kinds of nutrients. Among animal and vegetable protein products, fish is still the preferred source of protein and is a safe source of protein (Nurjanah et al. 2010). The consumption of fish on an industrial or household scale makes fish as primary raw substances. This means that parts of fish, excluding their meat, are referred to as by-products. The average portion of edible meat (edible portion) is $40-50 \%$ (Trilaksani 2004). That means the rest parts of the fish are not to be eaten. The body parts of the fish which usually become waste are scales, skin, bones, gills, all internal organs, namely the pancreas, liver, heart, gonads, swimming bubbles, and intestines.

Based on the zero waste system concept carried out by the Silarsatu program (Integrated Waste Reactor Management System) (Kastaman et al. 2007), waste can be used as natural fertilizer or compost which is environment friendly. Fish can be utilized with the zero waste principle. Fish skin can be used as leather crafts, gelatin, and crackers. Fish bone, head, and fins contain omega-3 fatty acids and gelatin; or the parts can made bone 
flour, which contains calcium to feed cattle. . "Fish innards" contain enzymes and fish oil, which are used as fish sauce and silage (animal feed) (Trilaksani 2004). Fish scales are potential as an alternative source of collagen. The collagen found in scales of sardines in a dry weight is $50.9 \%$, red sea bream $37.5 \%$, and Japanese sea bass $41.0 \%$ (Nagai et al. 2004).

Kerandang fish (Channa pleurophthalmus Blkr) originated from Central Kalimantan is one type of freshwater fish of the Channidae family of which primary metabolites is used by many for consumption needs; while secondary metabolites in waste of Kerandang fish (Channa pleurophthalmus Blkr) which are burned to charcoal are said to be potentially useful in the field of health / pharmacy, as a cure for allergies (local wisdom). Yet, exploration of the potential has not been carried out. The potential of Kerandang fish so far has not been studied so much that it causes a lack of scientific information about secondary metabolites found in charcoal from waste of Kerandang fish (Channa pleurophthalmus Blkr). Therefore, through this study it is considered necessary to screen and identify the secondary metabolites found in charcoal from waste of Kerandang fish (Channa pleurophthalmus Blkr).

The aim of this study is to determine the types of secondary metabolites contained in charcoal from waste of Kerandang fish (Channa pleurophthalmus Blkr), namely in the scalp, scales, dorsal fin, pectoral fin, pelvic fin, anal fin and dried caudal fin. The fish parts are then burned to become charcoal.

\section{MATERIALS AND METHODS OF RESEARCH}

This research was conducted for 3 (three) months from January to March 2019 at UPT Materia Medica Batu. Sampling was carried out at Kereng Bengkirai Harbor, Lake Sebangau, Central Kalimantan.

The materials used include charcoal from waste of Kerandang fish (caudal fin, anal fin, dorsal fin, scales, scalp, pelvic fin and pectoral fin), aquadest, Mg powder, Dragendorf reagent, Meyer reagent, Bouchardat reagent, concentrated $\mathrm{HCl}, \mathrm{FeCl} 31 \%, 70 \%$ ethanol, $96 \%$ ethanol, $50 \%$ Follin-Ciocalteau reagent, $7.5 \%$ sodium carbonate solution.

The apparatus used include: test tubes, test tube clamps, stainless steel spatulas, drop pipettes, measuring cup, bunsen, glass funnel, micro pipette, beaker glass, incubator, 1000 $\mathrm{ml}$ erlenmeyer, vacuum filter, rotary evaporator.

The method of this research is exploratory research using qualitative analysis methods. The color test is used to determine the type of secondary metabolite compound in the crude extract of Kerandang fish (Channa pleurophthalmus Blkr), which is indicated by the color change of the extract after the addition of certain reagents. The parameters include flavonoids, alkaloids, tannins, terpenoids, polyphenols and saponins. The data obtained are presented in table form and analyzed descriptively and drawn into a conclusion.

Fresh samples consist of waste from Kerandang fish, namely caudal fin, anal fin, dorsal fin, scales, scalp, pelvic fin and pectoral fin, each of which weighs in 1000 grams. Each sample was dried in the sun for 2-3 days, and then burned to become charcoal in a modified oven at $200^{\circ} \mathrm{C}$ for 7 minutes. The charcoal produced is then crushed so that the charcoal is produced in powder form.

Extraction was done by maceration method using $70 \%$ ethanol solvent in each sample. The dry samples used were 50 grams each, which were to be put in 7 (seven) $1000 \mathrm{ml}$ erlenmeyers and then added $500 \mathrm{ml}$ ethanol solvent, left for 24 hours, and filtered using a vacuum filter. The filtrate was then dried in a rotary evaporator. The supernatant obtained is a crude extract which will be further tested.

The testing / screening and identifying of the secondary metabolites from crude extracts of Kerandang fish (Channa pleurophthalmus Blkr) refers to the method of the Harborne (1984), which is modified as follows:

Identification of Flavonoids. $2 \mathrm{ml}$ of sample extract was added $8 \mathrm{ml}$ of aquadest which had been heated for \pm 10 minutes. The resulting filtrate was filtered and put in a test tube. Then a few drops of concentrated $\mathrm{HCl}$ is added. Next, a little $\mathrm{Mg}$ powder is added. Positive results show when dark red / pink colored filtrate is produced. 
Identification of Alkaloids. $2 \mathrm{ml}$ of sample extract was added $8 \mathrm{ml}$ of aquadest which had been heated for \pm 10 minutes. The resulting filtrate is filtered and put in a test tube. Then 6 drops of Meyer reagent were added to the first test tube, 6 drops of Dragendorf reagent to the second test tube, 6 drops of Bouchardat reagent to the third test tube. Positive results show when white sediment is produced in Meyer's reagents, orange sediment deposits in Dragendorf reagents and brown sediment deposits in Bouchardat reagents.

Identification of Tanins. $2 \mathrm{ml}$ of sample extract was added $8 \mathrm{ml}$ of aquadest which had been heated for \pm 10 minutes. The resulting filtrate is filtered and put in a test tube. Three drops of $\mathrm{FeCl} 31 \%$ were added to the filtrate. Positive results show when either blackish brown, blackish blue, or blackish green colored filtrate is produced.

Identification of Terpenoids. $2 \mathrm{ml}$ of sample extract was added $8 \mathrm{ml}$ of aquadest which had been heated for \pm 10 minutes. The resulting filtrate is filtered and put in a test tube. Three drops of Bouchardat were added to the filtrate. Positive results contain steroids when bluish green colored filtrate is formed, and the results contain pentenoids when a brownish orange colored filtrate is formed.

Identification of Polyphenols. A total of $105 \mu \mathrm{g}$ of methanol extract was put into $206 \mathrm{I}$ of $96 \%$ ethanol in a test tube. The mixture was added $515 \mu \mathrm{L}$ of distilled water and $510 \mu \mathrm{L}$ of Follin-Ciocalteau reagent $(50 \% \mathrm{v} / \mathrm{v})$, then the mixture was left for 5 minutes. Then it was added $103 \mu \mathrm{L}$ sodium carbonate solution $(7.5 \% \mathrm{~b} / \mathrm{v})$, homogenized and incubated at room temperature for 1 (one) hour under no-light conditions (dark). Positive results show when either blackish green, blackish blue, or blackish brown colored filtrate is formed.

Identification of Saponins. $2 \mathrm{ml}$ of sample extract was added $8 \mathrm{ml}$ of aquadest which had been heated for \pm 10 minutes. The resulting filtrate is filtered and put in a test tube. Two $\mathrm{ml}$ of hot water was added to the filtrate. The test tube containing the filtrate was then shaken firmly. Positive results show when the permanent foam is not lost.

\section{RESULTS AND DISCUSSION}

The results of the secondary metabolite screening and the secondary metabolite test with color are shown in Table 1 below:

Table 1 - Units for Properties

\begin{tabular}{|c|c|c|c|c|c|c|c|}
\hline \multirow{2}{*}{ No } & \multirow{2}{*}{ Sample name } & \multicolumn{7}{|c|}{ Identification of Metabolite Compounds } \\
\cline { 3 - 8 } & Caudal fin & A & B & C & D & E & F \\
\hline 1 & Anal fin & - & - & - & - & - & + \\
\hline 2 & Dorsal fin & - & - & - & - & - & + \\
\hline 3 & Scales & - & - & - & - & - & + \\
\hline 4 & Scalp & - & - & - & - & - & + \\
\hline 5 & Pelvic fin & - & - & - & - & + \\
\hline 6 & Pectoral fin & - & - & - & - & - & + \\
\hline 7 & &
\end{tabular}

Note: $A=$ Flavonoids $;=$ Tannins $; E=$ Polifenols; $B=$ Alkaloids; $D=$ Terpenoids; $F=$ Saponins.

Qualitatively, the secondary metabolic screening results show that all ethanol extracts of Kerandang fish (Channa pleurophthalmus Blkr) with ethanol solvents contain negative (-) flavonoids; contain (-) alkaloids, contain (-) tannins; contain (-) terpenoids; and contain (-) polyphenols; however, the extracts contain positive $(+)$ saponin compounds.

No identification of flavonoids, alkaloids, tannins, terpenoids and polyphenols is said to tend to be semipolar (Harborne, 1984), possibly because it has been directly bound by polar solvents (ethanol) during the initial maceration process.

Saponins, according to Firdous et al. (2009); Apri (2014), is a non-polar active compound which has a strong surface and can create foam when the compound is shaken with water. Marliana et al. (2005); Octaviani (2009) state that the emergence of foam indicates the presence of glycosides which have the ability to form foam in hydrolyzed water into glucose and other compounds. This can happen because saponin compounds also have a hydrophobic group, namely aglycone. The saponin structure consists of aglycones 
(triterpene or steroids) and glucose groups. The process of synthesizing glycosides is a detoxification process. In this detoxification process, it is possible for toxic compounds to be bound to crude extracts.

Farnsworth (1996); Bakhuni (2005); Yoshikawa et al. (2005); Ruiz et al. (2005); Zhang et al. (2006) state that saponins has many biological and pharmacological functions, including hemolysis, cardiotonic, hypoglycemic, hypocholesterolemic, immune modulator, hepatoprotection, antioxidant, anti-cardiogenic, anti-microbial, anti-inflammatory, low toxicity. Sapponins may function as anti-biotics and cholesterol-lowering agent, and it may also have biological effects, including as an anti-fungal, cytotoxic against tumor cells, hemolysis, immune activity, and anti-cancer.

\section{CONCLUSION}

The secondary metabolites contained in charcoal from waste of Kerandang fish (Channa pleurophthalmus Blkr), those which are in the scalp, scales, dorsal fin, pectoral fin, pelvic fin, anal fin and caudal fin are (+) Saponin compounds. The waste of Kerandang fish has the potential to be developed in the field of health / pharmaceutical as an anti-allergy.

\section{ACKNOWLEDGMENTS}

The authors express their gratitude to the Ministry of Finance and the Ministry of Research and Higher Education of the Republic of Indonesia for the opportunity given to obtain the 2016 LPDP BUDI-DN scholarship.

\section{REFERENCES}

1. Apri R. "The active compound content and phytochemical test of Sinularia sp. and Lobophytum sp. from the waters of Pongok Island, South Bangka." Institut Pertanian Bogor, Indonesian [Tesis], 2004.

2. Bhakuni R. "Bioactive Marine Natural Product." Anamaya Publishers, India, 2005.

3. Farnsworth N. R. "Biological and Phytochemical Screening of Plants." Journal of Pharm. Sci., Vol 5, No. 3, 1996.

4. Firdous M. "NIDDM antidiabetic activity of saponins of Momordica cymbalaria in streptozotocin-nicotinamide NIDDM mice," J. of Clin. Diagn. Res., 3: 1460-1465, 2009.

5. Harborne J.B. "Phytochemical methods, 2nd edition," Chapman And Hall Publications, Vol. 288, (Book style), 1984.

6. Kastaman R. "Integrated Waste Management System," Bandung, Indonesian, 2007.

7. Marliana S. "Phytochemical Screening and Thin Layer Chromatography Analysis of Chemical Pumpkin Fruit Components in Ethanol Extract," J. Biofarmasi. 3(1):26-31, 2005.

8. Nagai T. "Preparation and partial characterization of fish scale collagen," International Journal of Food Science and Technology, 39:239-244, 2004.

9. Nurjanah R. "Chemical and Physical Characteristics of Gouramy Scales (Osphronemus gouramy)," Jurnal Sumberdaya Perairan Akuatik. Vol. 4, No.2. Pp. 7-12, 2010.

10. Octaviani Y. "Isolation and Identification of Green Bean Sprout (Phaseolus radiates L.) Sprout Aglycones," Departement Farmacy, Universitas Sanata Dharma, 2009.

11. Ruiz N. "Chemical conditionality: a genetic strategy to probe organelle assembly," Journal of Cell. 12(2):307-317, 2005.

12. Trilaksani W. "Diversification and Processing of By-Products of Fishery Products," Department of Fisheries Products Technology. Institut Pertanian Bogor, 2004.

13. Yoshikawa M. "Bioactive saponins and glycosides. XXIII.1) triterpene saponins with gastroprotective effect from the seeds of Camellia sinensis teasaponins E3, E4, E5, E6, and E7," Journal of Chemical and Pharmaceutical Bulletin, 53(12):1559-1564, 2005.

14. Zhang B. "Prevention of ischemic neuronal death by intravenous infusion of a ginseng saponin, ginsenoside Rb1, that upregulates Bcl-xL expression," Journal of Cerebral Blood Flow \& Metabolism (2006) 26, 708-721, 2006. 